\title{
Troškovi zaduživanja i prinosi na hrvatske državne obveznice
}

\author{
ANTO BAJO Institut za javne financije \\ MARKO PRIMORAC Ekonomski fakultet Zagreb
}

Država novim zaduživanjima u 20I3. uglavnom financira otplate kamata i glavnice postojećeg duga. Primici od zaduživanja obveznicama već dugo vremena ne koriste se za financiranje kapitalnih ulaganja. Visoki rashodi za otplate glavnice i kamata duga rezultat su visokih proračunskih deficita koji povećavaju kreditni rizik što se odražava na porast troškova zaduživanja i na prinose državnih obveznica. Smanjenje deficita i javnog duga do 20I6. nije u planu postojeće Vlade, što bi moglo utjecati na daljnji rast prinosa na nova izdanja državnih obveznica.

\section{OSNOVE O TRŽİ̌NOM FINANGIRANJU PRORAČUNSKOG DEFICITA I PRINOSIMA NA DRŽAVNE OBVEZNICE}

Proračunski deficit može se financirati na nekoliko načina. Jedan od njih je zaduživanje države na domaćem ili inozemnom tržištu. Država se može zaduživati kreditima ili izdavanjem vrijednosnica - obveznica i trezorskih zapisa. Zaduživanje kreditima ima elemente diskrecijskog pregovaranja o uvjetima između predstavnika države i banaka. U odnosu na kredite, zaduživanje obveznicama je transparentnije jer veći broj tržišnih sudionika ocjenjuje kreditnu sposobnost države i natječe se u kupovini obveznice.

Prinos je ključni razlog za odluku investitorâ da ulažu u državne obveznice. U odnosu na kredite (koji vjerovniku donose samo zaradu od kamate), kupci državnih obveznica mogu ostvariti zaradu na temelju kuponske kamate (kod kuponskih obveznica), ali i razlikom kupovne i prodajne cijene obveznica. Prinos je zapravo ukupna zarada kupca obveznice koju čini kamata (tekući dio) i razlika u cijeni (kapitalni dio). Prinos na državnu obveznicu može se iskazati na više sličnih načina, a najčešće se koristi prinos do dospijeća.

Prinos do dospijeća (engl. yield to maturity - YTMM) ${ }^{\mathrm{r}}$ je ukupan prinos obveznice izražen godišnjom stopom, uz uvjete da se obveznica drži do dospijeća, da se kuponske isplate ponovno ulože (reinvestiraju) te da je povrat na ulaganje jednak stopi prinosa do dospijeća.

Kupnjom obveznice, investitori preuzimaju rizik o kojem ovisi očekivani prinos obveznice, a za veći preuzeti rizik ulaganja očekuju i veći prinos (zaradu). Što je veća neizvjesnost naplate potraživanja (kreditni rizik države), veći je i prinos do dospijeća državnih obveznica. Zbog promjene kreditnog rizika države, dolazi

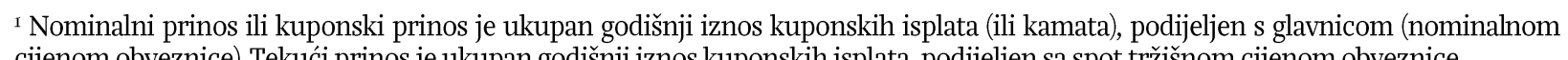
cijenom obveznice). Tekući prinos je ukupan godišnji iznos kuponskih isplata, podijeljen sa spot tržišnom cijenom obveznice. 
do promjena u ponudi i potražnji za državnim obveznicama na financijskom tržištu. Promjene u ponudi i potražnji utječu na promjene cijena obveznica, a s obzirom da prinos - između ostaloga - izravno ovisi o cijeni, mijenja se i prinos do dospijeća. Što je cijena po kojoj ulagač kupuje obveznice na tržištu manja, to je veći prinos koji ulagač može ostvariti držanjem obveznica do dospijeća.

\section{TrošKovi I UVJETI ZADUŽIVANJA}

Po računici Vlade i Ministarstva financija, od 2013. do 2015. prosječni deficit proračuna opće države održavat će se iznad 4\% BDP-a, a prema izračunima Eurostata u prosjeku je veći i iznosi 6\% BDP-a (v. grafikon I). Država se od 2002. do 2012. godišnje zaduživala u rasponu od I,5 mlrd. kuna (2007.) do 16,5 mlrd. (2009.). Međutim, samo u prvih 9 mjeseci 2013. zadužila se I8,I mlrd. kuna. Javni dug već u 2013. prelazi razinu od 60\% BDP-a, a po svemu sudeći do 2016. mogao bi porasti na 65\% BDP-a (v. grafikon 2).

Povećanjem zaduživanja rastu godišnji rashodi za kamate s 3,3 mlrd. 2002. na 8,3 mlrd. 2012., a 2016. će iznositi oko 13 mlrd. kuna. Ukoliko ne dođe do značajnog gospodarskog rasta, rashodi za kamate će s 1,5\% BDP-a 2008. porasti na čak 3,5\% BDP-a 2016. (v. grafikon 3). Iznos rashoda za kamate prilično je visok u nekim godinama čak i veći od iznosa deficita. To znači da se država zadužuje isključivo za pokriće troškova prijašnjih zaduživanja.

Za ocjenu troškova zaduživanja potrebne su cjelovite informacije o kreditima i izdanim obveznicama. Nažalost, temeljem dostupnih informacija može se steći uvid samo u glavna obilježja zaduživanja Hrvatske izdanjima obveznica, ali ne i podatke o kreditima.

Hrvatska se od osamostaljenja zaduživala obveznicama na domaćem i inozemnom financijskom tržištu, u hrvatskim dinarima, kunama, njemačkim markama, eurima i američkim dolarima, a od 1999. do 2003. i u japanskim jenima.

Od 1991. do 2013. država je izdala oko 60 obveznica na domaćem i inozemnom tržištu kapitala, za financiranje izvršavanja državnog proračuna, refinanciranje obveza, podmirenje obveza prema vjerovnicima HZZO-a, isplate štednih uloga te za stvaranje uvjeta za restrukturiranje gospodarstva. Ukratko, primici od zaduživanja obveznicama korišteni su uglavnom za financiranje tekućih rashoda, a krediti su u većoj mjeri korišteni za financiranje kapitalnih ulaganja.

Od 1991. do 2013. prosječan prinos pri izdanju obveznica je 5,58\%. Najmanji prinos je 1,23\% na tzv. Samuraj obveznicu izdanu 2003. za izvršavanje državnog proračuna. To je uvjerljivo najpovoljnije zaduživanje obveznicama u hrvatskoj povijesti. S druge strane, najviši ostvareni prinos od 7,4485\% je na obveznicu izdanu 1999. na inozemnom tržištu kapitala.

Prosječni rok dospijeća obveznica je oko 7,5 godina. Obveznice s najkraćim rokovima dospijeća (I godina) izdavane su početkom devedesetih, a s najdužim (Io godina) tijekom 20oo-tih. Treba istaknuti da država nije izdavala obveznice 1993., 1995. i 2008. U 2013. ukupno je aktivna 21 obveznica od kojih 12 kotira na domaćem, a 9 na inozemnom tržištu kapitala.

Do 2024. državi će kumulativno stići na naplatu II4 mlrd. kuna duga glavnice po izdanim obveznicama (v. grafikon 4). Struktura utrživog duga po rokovima dospijeća prilično je neujednačena. Primjerice, 2016. na naplatu dospijeva 3,5 mlrd. kuna glavnice, a 2017. gotovo $18 \mathrm{mlrd}$. Tako visoki pritisci refinanciranja obveza mogu potkopati povjerenje ulagača $u$ sposobnost otplate duga (primjerice $u$ 2017.), zbog čega može porasti njihova procjena kreditnog rizika Hrvatske. To je dovoljan razlog za rast prinosa do dospijeća hrvatskih obveznica zbog povećanja njihove ponude na tržištu i smanjenja potražnje te neizravno smanjenja cijene. Povećanje prinosa na financijskom tržištu stavlja državu u nepovoljniji pregovarački položaj o uvjetima zaduživanja izvan tržišta (kod banaka), što se nepovoljno odražava i na troškove zaduživanja (kamatnu stopu). 


\section{PRINOSI NA HRVATSKE DRŽAVNE OBVEZNICE}

Na domaćem financijskom tržištu 2013. kotira 26,25 mlrd. kuna i 4,25 mlrd. eura državnih obveznica (ukupno 7,7 mlrd. eura ili 58,6 mlrd. kuna). ${ }^{2}$ Prosječan prinos pri izdanju obveznica je 5,804\%. Posljednje izdanje obveznica na domaćem tržištu obavljeno je u srpnju 2013. Tada je izdano 2,75 mlrd. kuna i 750 mil. eura obveznica s rokom dospijeća od 5 i II godina. Kuponska kamatna stopa nedospjelih obveznica kreće se u rasponu od 4,25 do 6,75\%, a cijena od 97,IOI do nominalnog iznosa Ioo (odnosno od 97,IOI\% do IOO\% nominalnog iznosa). Različite kombinacije kamatnih stopa, cijena i rokova dospijeća rezultirale su i različitim prinosima pri izdanju obveznica.

Tablica I.

Aktivne obveznice izdane na domaćem tržištu

\begin{tabular}{|c|c|c|c|c|c|c|c|c|}
\hline $\begin{array}{l}\text { Obveznica } \\
\text { RHMF-O-: }\end{array}$ & $\begin{array}{c}\text { Iznos } \\
\text { (u mil.) }\end{array}$ & Valuta & $\begin{array}{c}\text { Kamatna } \\
\text { stopa } \\
(\mathbf{u} \%)\end{array}$ & $\begin{array}{c}\text { Gijena } \\
\text { pri } \\
\text { izdanju }\end{array}$ & $\begin{array}{c}\text { Prinos } \\
\text { pri } \\
\text { izdanju }\end{array}$ & Izdanje & Dospijeće & $\begin{array}{c}\text { Broj } \\
\text { isplata } \\
\text { kupona }\end{array}$ \\
\hline $\mathrm{I} 42 \mathrm{~A}$ & 650 & EUR & 5,500 & 98,II9 & 5,750 & 10.2.2004. & I0.2.2004. & 2 \\
\hline I9BA & 500 & EUR & 5,375 & 99,655 & 5,409 & 29.II.2004. & 29.II.2OI9. & 2 \\
\hline I57A & 350 & EUR & 4,250 & 98,845 & 4,394 & 14.7 .2005 & 14.7 .2015 & 2 \\
\hline I5CA & 5.500 & HRK & 5,250 & 100,000 & 5,250 & I5.I2.2005. & 15.12.2OI5. & 2 \\
\hline $\mathrm{I} 72 \mathrm{~A}$ & 5.500 & HRK & 4,750 & 98,748 & 4,910 & 8.2.2007. & 8.2.20I7. & 2 \\
\hline $203 \mathrm{~A}$ & 5.000 & HRK & 6,750 & 98,575 & 6,950 & 5.3.2010. & 5.3.2020. & 2 \\
\hline $2 \mathrm{O} 3 \mathrm{E}$ & I.OOO & EUR & 6,500 & 98,559 & 6,700 & 5.3.2010. & 5.3.2O2O. & 2 \\
\hline $\mathrm{I} 7 \mathrm{BA}$ & 4.000 & HRK & 6,250 & 98,998 & 6,430 & 25.II.2OIO. & 25.II.2OI7. & 2 \\
\hline $167 \mathrm{~A}$ & 3.500 & HRK & 5,750 & 99,146 & 5,950 & 22.7.2OII. & 22.7 .2016 & 2 \\
\hline $227 \mathrm{E}$ & 1.000 & EUR & 6,500 & 97, IOI & 6,880 & 22.7.2OII. & $22.7 .2 \mathrm{O} 22$ & 2 \\
\hline $187 \mathrm{~A}$ & 2.750 & HRK & 5,250 & 99,957 & 5,260 & 10.7.2013. & 10.7.2018. & 2 \\
\hline $247 \mathrm{E}$ & 750 & EUR & 5,750 & 99,919 & 5,760 & I0.7.20I3. & I0.7.2024. & 2 \\
\hline Prosjek & & & 5,656 & 98,969 & 5,804 & & & \\
\hline Prosjek HRK & & & 5,667 & 99,237 & 5,792 & & & \\
\hline Prosjek EUR & & & 5,646 & 98,700 & 5,815 & & & \\
\hline
\end{tabular}

Izvor: Bloomberg (20I3b)

Na inozemnom tržištu kotiraju obveznice u iznosu od 2 mlrd. eura i 9 mlrd. dolara (ukupno oko 65,5 mlrd. kuna). Prosječan prinos pri izdanju obveznica je 6,265\%, a kretao se u rasponu od 5,II do 7,009\%. Različiti prinosi do dospijeća rezultat su (osim različitih kuponskih kamatnih stopa, cijena obveznica i rokova dospijeća) razlika u načinu isplate kuponskih kamata koje se isplaćuju godišnje ili polugodišnje. Za domaće obveznice isplata kupona je isključivo polugodišnja, a za inozemne kombinacija polugodišnjih i godišnjih.

\footnotetext{
2 Za preračunavanje iznosa glavnice obveznica denominiranih u drugim valutama u kune korišten je srednji devizni tečaj HNB-a za
} listopad 20I3. (mjesečni prosjek) od 7,6I44I9 kuna za I euro i 5,5857I4 kuna za I američki dolar. Ti se tečajevi koriste i u nastavku rada. 
Tablica 2.

Aktivne obveznice izdane na inozemnom financijskom tržištu

\begin{tabular}{|c|c|c|c|c|c|c|c|c|}
\hline $\begin{array}{l}\text { Obveznica } \\
\text { Euro bond: }\end{array}$ & $\begin{array}{c}\text { Iznos } \\
(\mathbf{u} \text { mil. })\end{array}$ & Valuta & $\begin{array}{c}\text { Kamatna } \\
\text { stopa } \\
(\mathbf{u} \%) \\
\end{array}$ & $\begin{array}{c}\text { Gijena } \\
\text { pri } \\
\text { izdanju }\end{array}$ & $\begin{array}{c}\text { Prinos } \\
\text { pri } \\
\text { izdanju }\end{array}$ & Izdanje & Dospijeće & $\begin{array}{c}\text { Broj } \\
\text { isplata } \\
\text { kupona }\end{array}$ \\
\hline VI & 500 & EUR & $5, \mathrm{OOO}$ & 99,155 & 5,IIO & I5.4.2004. & I5.4.20I4. & I \\
\hline VII & 750 & EUR & 6,500 & 99,675 & $6,57 \mathrm{I}$ & 5.6.2009 & 5.I.2OI5. & I \\
\hline $\mathrm{I}$ & I.500 & USD & 6,750 & 98,160 & 7,009 & 5.II.2009. & 5.II.2OI9. & 2 \\
\hline II & 1.250 & USD & 6,625 & 99,IO2 & 6,750 & 14.7.2OIO. & 14.7 .2020 & 2 \\
\hline III & 1.500 & USD & 6,375 & 98,250 & 6,617 & 24.3.2OII. & 24.3.2O2I. & 2 \\
\hline VIII & 750 & EUR & 5,875 & 98,600 & 6,127 & 8.7.2OII. & 9.7.2018. & I \\
\hline $\mathrm{IV}$ & I.5OO & USD & 6,250 & 99,472 & 6,375 & $27.4 .2 \mathrm{OI} 2$ & 27.4.2OI7. & 2 \\
\hline $\mathrm{V}$ & I.5OO & USD & 5,500 & 99,054 & 5,625 & 4.4.20I3. & 4.4.2O23 & 2 \\
\hline IX & I. 750 & USD & 6,000 & 98,488 & 6,203 & 26.II.2OI3. & 26.I.2O24. & 2 \\
\hline Prosjek & & & 6,097 & 98,884 & 6,265 & & & \\
\hline Prosjek EUR & & & 5,792 & 99,I43 & 5,936 & & & \\
\hline Prosjek USD & & & 6,250 & 98,754 & 6,430 & & & \\
\hline
\end{tabular}

Izvor: Bloomberg $(2 \mathrm{OI} b)$

Posljednje izdanje obveznica na inozemnom tržištu u iznosu od 1,75 mlrd. dolara u velikoj mjeri odražava očekivanja investitora o kretanju kreditnog rizika Republike Hrvatske. Prinosi na to izdanje čak su za 0,578\% veći od prinosa na izdanja obveznica sličnih obilježja (dva puta po 1,5 mlrd. dolara), obavljena oko pola godine ranije. Iako prilikom ocjene troška zaduživanja treba imati u vidu i tržišno okruženje, porast prinosa na dolarske obveznice svjedoči da je kod investitora pogoršana percepcija kreditne sposobnosti RH.

Prinosi na državne obveznice izdane na domaćem tržištu kapitala u prosjeku su za o,46r\% niži od prinosa na obveznice izdane na međunarodnom tržištu. Domaća izdanja obveznica u prosjeku su povoljnija za državu zbog manjih rizika, naime polovica je ukupnog iznosa obveznica na domaćem tržištu izdana $u$ kunama, što je umanjilo valutni rizik naplate (prihodi Državnog proračuna ostvaruju se u kunama).

U prosjeku, za državu su najniži troškovi zaduživanja obveznicama u kunama i eurima - prosječan prinos na šest aktivnih kunskih obveznica je 5,792\%. Prosječan prinos na devet obveznica izdanih u eurima (šest domaćih i tri inozemne) je 5,856\%, a prinos na šest inozemnih obveznica izdanih u dolarima je 6,43\%. Lako je izračunati da je prinos na zaduživanje obveznicama u kunama manji od onih u eurima za o,o64, a od obveznica izdanih u dolarima za čak o,638\%.

Treba istaknuti da je država barem $u$ četiri (od šest) izdanja inozemnih obveznica denominiranih $u$ dolarima koristila i valutnu zamjenu (engl. swap) kojom je nastojala umanjiti rizik promjene tečaja valute - valutni rizik. Međutim, valutnom zamjenom država se štitila od promjene tečaja dolara u odnosu na euro, a ne u odnosu na kunu ( $\mathrm{u}$ kojoj ostvaruje prihode). Razlog tome je vjerojatno činjenica da investitori nisu voljni preuzeti rizik promjene tečaja kune (ili bi cijena takvog osiguranja bila prilično visoka). Valutna zamjena zasigurno je dodatno povećala troškove zaduživanja države u dolarima. Nažalost, ne postoje javno dostupne informacije o detaljima ugovora o valutnoj zamjeni zbog čega nije moguće utvrditi ukupan trošak zaduživanja u dolarskim obveznicama.

Hrvatska ima strukturiranu kunsku i krivulju prinosa u eurima (v. grafikone 5 i 6) Krivulje su normalnog oblika, što znači da prinosi rastu s povećanjem roka dospijeća. Vlada RH bi narednim izdanjima trebala i dalje nastojati upotpuniti i produljiti krivulju prinosa. Za kunsku krivulju prinosa treba izdati obveznicu s rokom dospijeća sredinom 2019. i nakon 2020. Za krivulju prinosa u eurima nedostaju podaci o prinosima duga s dospijećem 2017. ili 20I8. Ukoliko bi dospijeća obveza u većoj mjeri opteretila državni proračun u navedenim godinama, tada izdanja ne bi smjela biti velika. Za razvoj financijskog tržišta bolje je imati više manjih izdanja obveznica različitih rokova dospijeća nego manje izdanja s velikim iznosima obveza. 


\section{PRINOSI NA DRŽAVNE OBVEZNICE HRVATSKE I ZEMALJA ČLANIGA EU-A}

Ugovorom iz Maastrichta, utvrđeno je pet kriterija konvergencije koje zemlje članice Unije moraju udovoljavati da bi uvele euro. Jedan od kriterija je i zadržavanje dugoročnih kamatnih stopa - prosječnih prinosa na desetogodišnje državne obveznice u prošloj godini - na razini koja ne prelazi za više od $2 \%$ neponderiranu aritmetičku sredinu prinosa na slične desetogodišnje obveznice $u$ tri članice EU-a $s$ najnižom inflacijom. ${ }^{3}$ Zbog toga od 1993. prinosi na državne obveznice zemalja članica EU-a počinju konvergirati da bi već od svibnja 2000. gotovo u potpunosti konvergirale i to na razini nižoj od 5\% (v. grafikon 7). Prinosi na dugoročne obveznice pojedinih zemalja (primjerice Grčke) bili su i prije financijske krize prilično visoki. Ulaskom zemalja u EU, te posebice prihvaćanjem eura, za investitore (vjerovnike) značajno se smanjuju ili eliminiraju brojni rizici (politički, valutni itd.), pa investitori trgovanjem poništavaju eventualne razlike u prinosima. To se naročito potvrdilo u razdoblju od 2000. do 2007.

U uvjetima financijske nestabilnosti, investitori su postali osjetljivi na rizik, pa i minimalne razlike u stabilnosti pojedinih država postaju iznimno značajne. Tako od 2008. prinosi državnih obveznica članica EU-a značajno divergiraju jer su investitori različito ocijenili financijsku perspektivu država i njihov kreditni rizik. Iako su sve zemlje članice EU-a pogođene financijskom krizom, ona se različito odrazila na njihovu fiskalnu poziciju. Investitori su povećavali ulaganja u obveznice država koje su relativno otpornije na posljedice krize što je, posredstvom utjecaja na cijenu obveznica (koja odražava odnos ponude i potražnje), utjecalo na smanjenje prinosa na sigurnije obveznice i povećanje prinosa na obveznice rizičnijih EU zemalja. Najočitiji primjer su prinosi na državne obveznice Grčke koji su - zbog opasnosti od bankrota - dosezali gotovo 30\%. Investitori su obveznice rasprodavali radi povrata barem dijela uloženih sredstava. Prilikom restrukturiranja portfelja, ulagači su kupovali obveznice najsigurnijih zemalja (prije svega Njemačke) čiji su se prinosi (zbog povećane potražnje) smanjivali. Njemačke obveznice (popularni Bund) gotovo kontinuirano imaju najniže i najstabilnije prinose. Ti se prinosi uzimaju i kao referentni (nerizični) prinosi u Europi, a prinosi ostalih zemalja utvrđuju se uz premiju na prinose njemačkih obveznica.

Od 20Io. Eurostat statistički prati prinose na državne obveznice Hrvatske. U usporedbi s drugim članicama EU-a, Hrvatska je u kategoriji država s većim kreditnim rizikom (grafikon 7). Sudeći po visini prinosa, nalazi se u kategoriji mediteranskih zemalja i Irske, dakle zemalja koje su u većoj mjeri pogođene financijskom krizom. To su prepoznali i investitori koji traže i veći prinos na obveznice. Prinosi obveznica Hrvatske su uz bok obveznicama Italije i Španjolske. Ukoliko država ne bude imala aktivniju ulogu u upravljanju državnim financijama i javnim dugom, postoji opasnost daljnjeg rasta troškova zaduživanja i prinosa na državne obveznice.

Prinosi obveznica Hrvatske su iznad prosjeka zemalja EU-a (grafikon 8). Isto tako, očekivano su znatno veći nego dugoročni prinosi na njemačke, ali ipak osjetno manji od prinosa na grčke obveznice. Prinosi na Hrvatske obveznice su približavanjem EU-a konvergirali njemačkima, no pojavom financijske krize prinosi divergiraju i širi se razlika (raspon) prinosa hrvatskih i njemačkih obveznica. Razlog je porast relativnog rizika Hrvatske $u$ odnosu na Njemačku. Međutim, u odnosu na većinu zemalja u kojima je trend kretanja prinosa silazan, prinosi obveznica Hrvatske rastu.

\section{HRVATSKA MORA SMANJITI TROŠKOVE ZADUŽIVANJA}

Ulazak Hrvatske u EU pozitivno je utjecao na uvjete zaduživanja - da nije postala članica, troškovi duga vjerojatno bi bili još veći. Potencijalni ulazak u EMU i prihvaćanje eura kao službene valute zasigurno bi dodatno smanjio trošak duga (zbog uklanjanja valutnog rizika).

Europska komisija će zbog visoke razine proračunskog deficita i javnog duga nad Hrvatskom pokrenuti postupak prekomjernog proračunskog deficita (PPPD). To je za investitore dodatan poziv na oprez, zbog

${ }^{3}$ Kao mjera inflacije pritom se koristi harmonizirani indeks potrošačkih cijena (engl. Harmonised Index of Consumer Prices - HICP). 
čega će prinosi na državne obveznice, a posredno i troškovi zaduživanja vjerojatno rasti. Međutim, ulazak u PPPD je svojevrsno čistilište nakon kojeg se prinosi mogu znatno smanjiti uslijed pridržavanja fiskalnih pravila EU-a što pozitivno utječe na kreditni rizik. Ukoliko se u sklopu PPPD-a Hrvatska bude predano pridržavala pravila i spustila deficit ispod 3\% BDP-a, to bi se lako moglo odraziti i na smanjenje prinosa na državne obveznice te općenito na troškove zaduživanja. Zbog toga bi Vlada RH morala u što kraćem roku predložiti kvalitetne i realistične mjere za smanjenje proračunskog deficita koje bi u kratkom roku mogle zadržati postojeću razinu povjerenja ulagača.

Ministarstvo financija - Sektor za upravljanje dugom - treba pohvaliti, jer su dosadašnjim izdanjima obveznica uspjeli izgraditi krivulje prinosa i sve bolje podešavaju ročnu strukturu javnog duga. Tako razborito ponašanje potpora je razvoju domaćeg financijskog tržišta i upravljanju državnim financijama. Ipak, postoji značajan prostor za poboljšanje ročne strukture duga (ujednačavanje rasporeda dospijeća duga) radi ravnomjernijeg rasporeda tereta otplate.

\section{PREPORUKE}

Vlada i Ministarstvo financija mogli bi s nekoliko tehničkih mjera značajno smanjiti troškove zaduživanja i izloženost države kreditnim rizicima.

Novim izdanjima obveznica država bi ponovno mogla okušati sreću na azijskim tržištima (prije svega $u$ Japanu i Kini). Ta su tržišta sklonija riziku, pa bi trošak zaduživanja vjerojatno bio niži nego na ostalim tržištima, čak i kada bi se ukupnim troškovima dodali i troškovi zaštite od valutnog rizika.

Treba se zaduživati na domaćem tržištu kapitala. Hrvatska treba na domaćem tržištu institucionalnim investitorima ponuditi više obveznica manje nominalne vrijednosti. Unatoč značajnoj štednji, teško je očekivati da će država izdati štedne obveznice i prodavati ih stanovništvu. Glavni je razlog slabi kredibilitet Vlade i općenito nepovjerenje stanovništva zbog slabog financijskog upravljanja i neadekvatnih reformskih mjera.

Ministarstvo financija treba zauzeti aktivniju poziciju na tržištu, otkupljujući obveznice u slučajevima smanjenja cijene te refinancirati skuplje dugove jeftinijim izvorima financiranja koji se povremeno pojavljuju na tržištu.

Vlada i Ministarstvo financija trebaju poboljšati i unaprijediti informiranje investitora, ali i stručne i šire zainteresirane javnosti o stanju i strukturi duga. Ministarstvo financija je do sada objavilo samo dva dokumenta u potpunosti posvećena tom problemu. To su Godišnje izvješće i Strategija upravljanja javnim dugom (2006.), te Strategija upravljanja javnim dugom za razdoblje 20II.-2013. (2011.). Osim što su neredovite, te publikacije ne nude sve relevantne podatke.

Valjalo bi poboljšati podatke o strukturi neutrživog dijela javnog duga (zaduživanje kreditima). Zbog nepostojanja detaljnih informacija o kreditnim zaduživanjima, investitori i šira zainteresirana javnost nemaju uvida u stvarne uvjete zaduživanja ni u strukturu dospijeća kredita. To je ograničenje i za inozemne investitore koji u prospektima izdanja hrvatskih obveznica ne mogu biti sigurni u vjerodostojnost podataka o javnom dugu, što dodatno povećava rizik ulaganja kao i očekivani prinos.

Ministarstvo financija treba redovito objavljivati kalendar izdavanja trezorskih zapisa (posljednji je dostupan za 2011.) i kalendar planiranih izdanja obveznica (posljednji je dostupan za 2007.). Objava kalendara izdavanja omogućila bi potencijalnim investitorima bolje upravljanje strukturom vlastite imovine i obveza, što bi dodatno moglo smanjiti zahtijevane prinose. 
Vlada žurno treba unaprijediti institucionalni i administrativni okvir upravljanja javnim dugom donošenjem zasebnog Zakona o javnom dugu, ali i osnivanjem izdvojene Agencije za upravljanje javnim dugom koja bi znatno učinkovitije obavljala povjerene zadaće.

\section{PRILOG}

\section{Grafikon I.}

Proračunski deficit opće države od 2009. do 20I6. (u \% BDP-a)

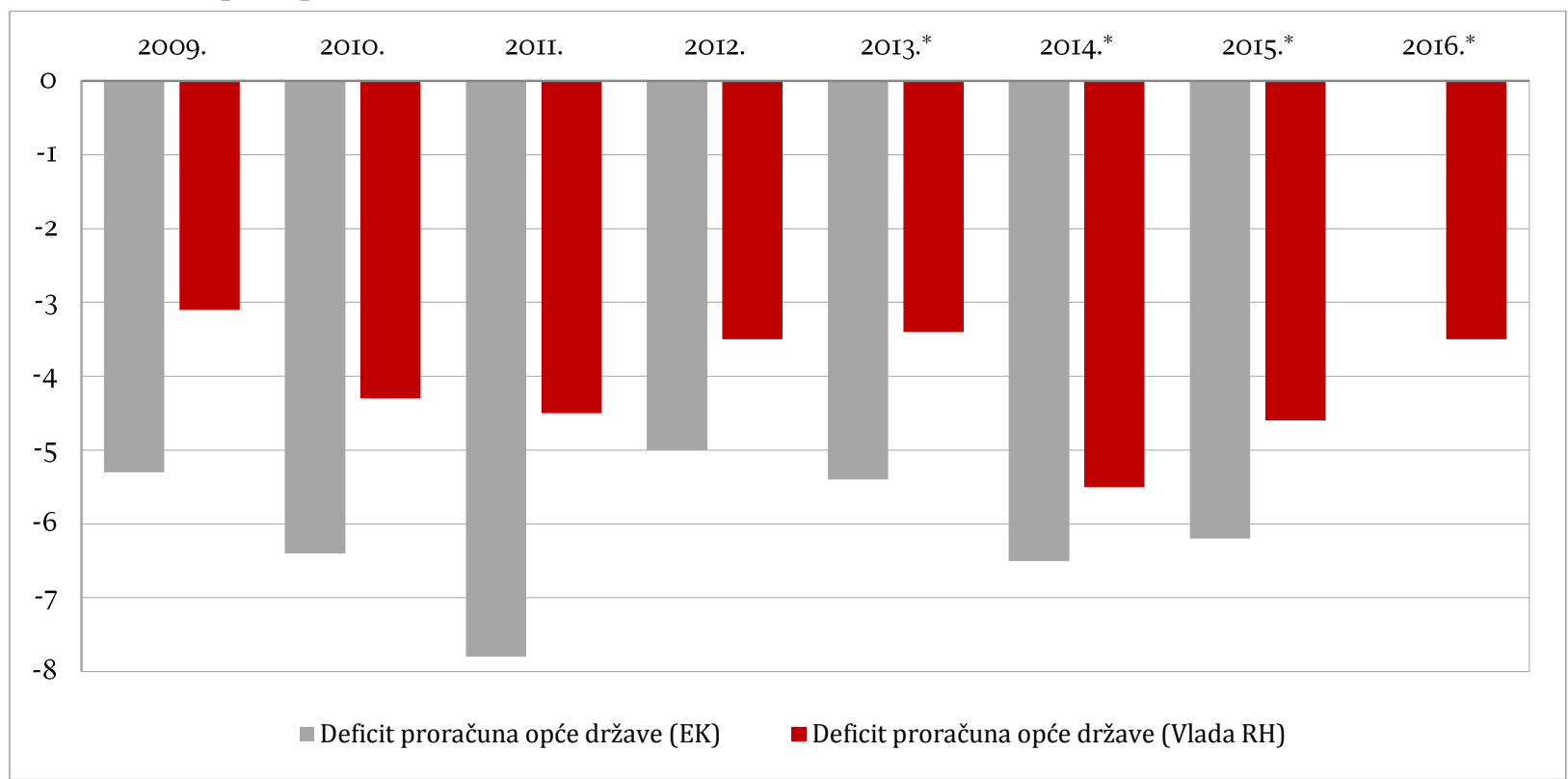

*Projekcija vrijednosti

Izvor: Ministarstvo financija (2013a); Eurostat (2013)

\section{Grafikon 2.}

Dug opće države od 2009. do 2016. (\% BDP-a)

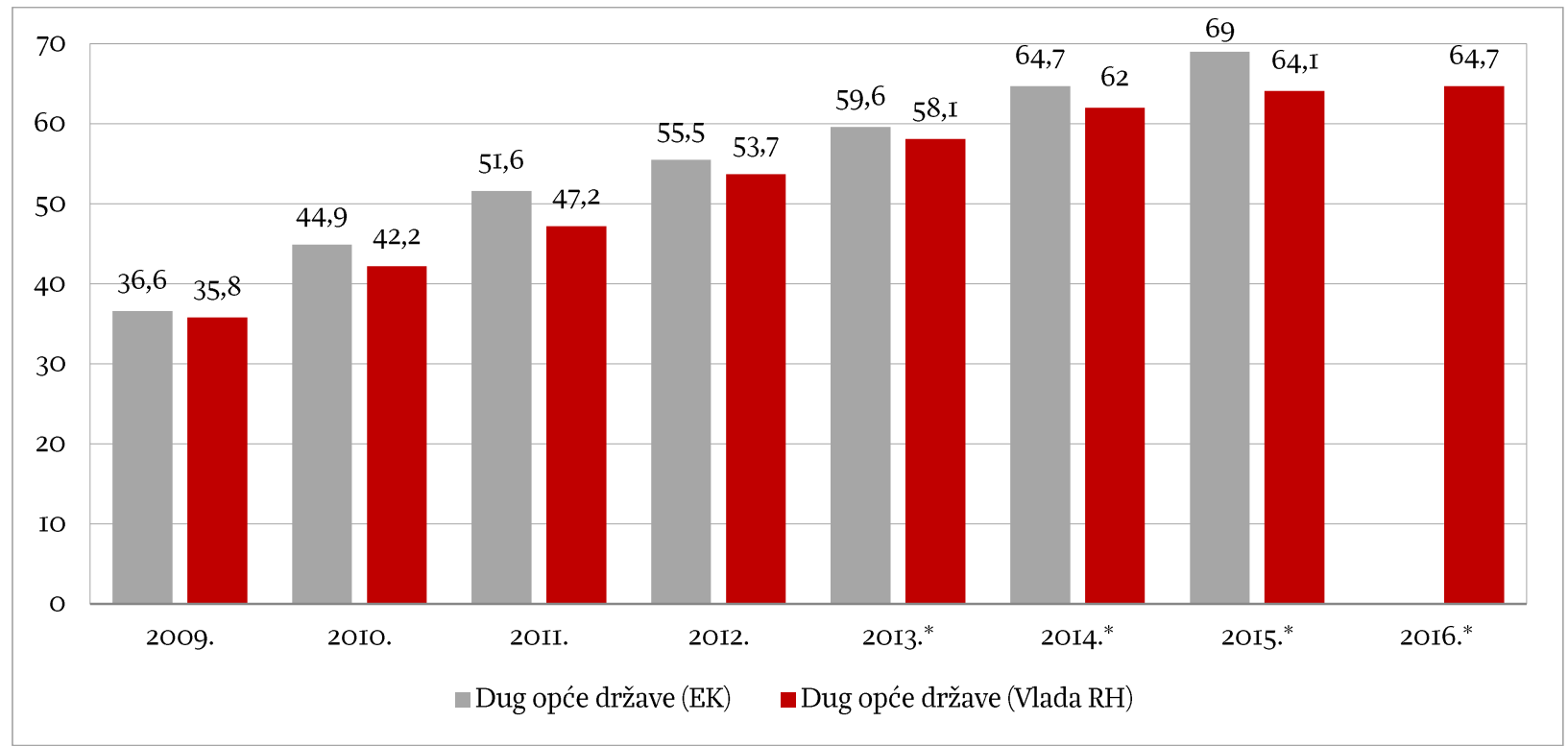

*Projekcija vrijednosti

Izvor: Ministarstvo financija (2013b); Eurostat (2013) 
Tablica 3.

Rashodi za kamate od 2002. do 20I6. (u mlrd. kuna i \% BDP-a)

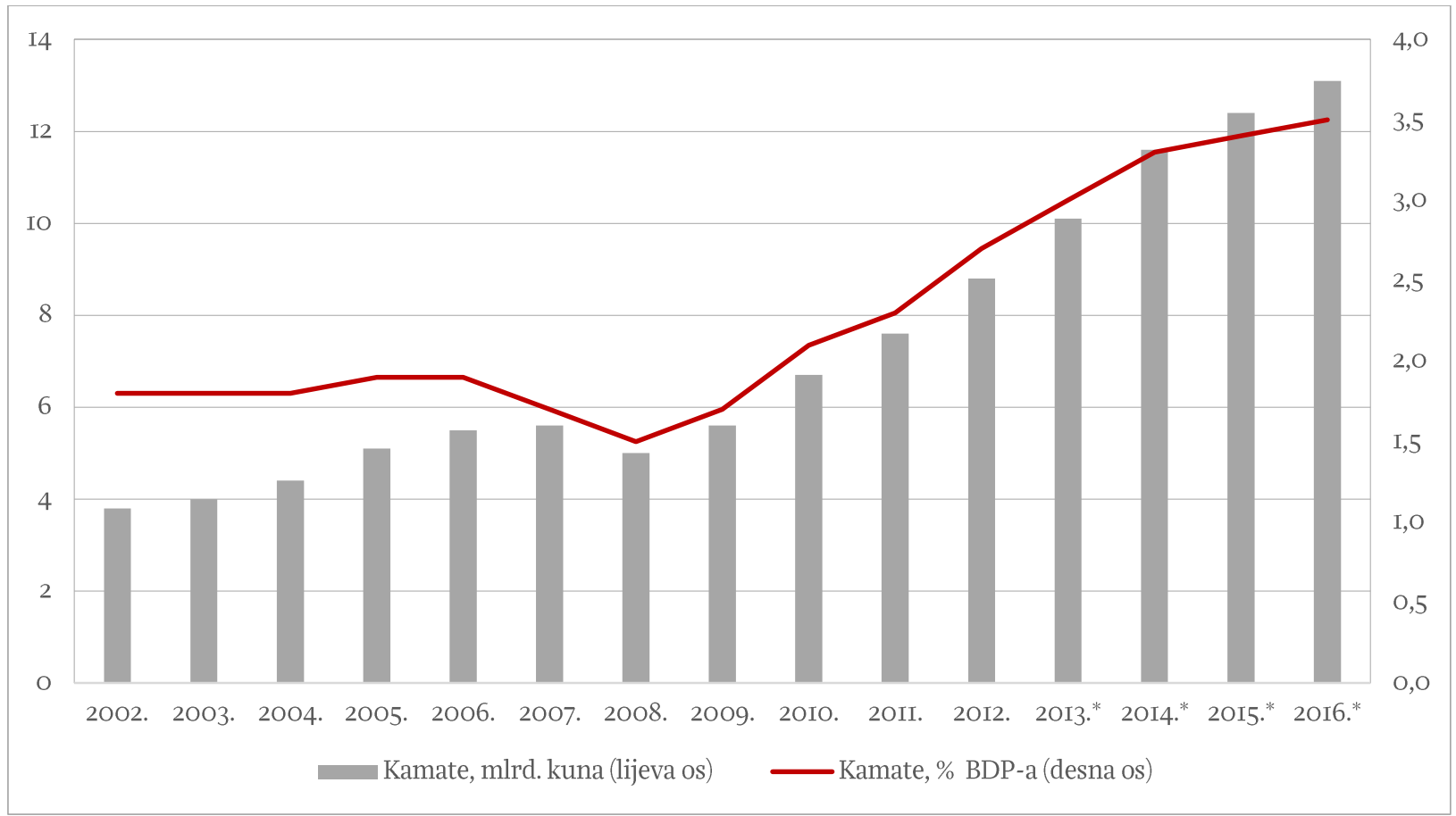

Izvor: Ministarstvo financija (20I3a)

\section{Grafikon 4.}

Projekcija dospijeća obveznica do 2024. (u mlrd. kuna)

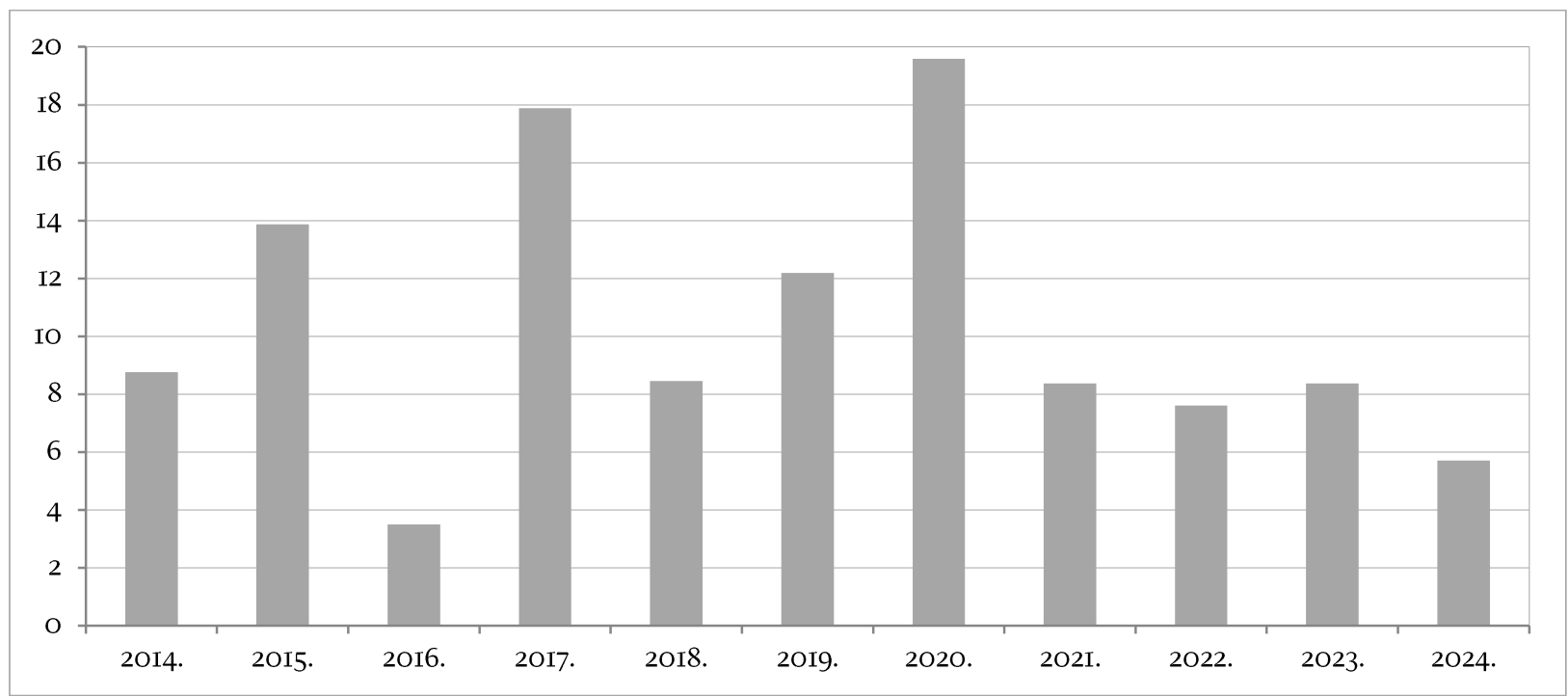

Napomena: Za preračunavanje iznosa glavnice obveznica denominiranih u drugim valutama u kune korišten je srednji devizni tečaj kuna za listopad 20I3. (mjesečni prosjek) od 7,6I44Ig kuna za I euro i 5,5857I4 kuna za I američki dolar.

Izvor: Autori, temeljem podataka Ministarstva financija 


\section{Grafikon 5.}

Prinosi do dospijeća obveznica Hrvatske, izdanih na domaćem tržištu denominiranih u kunama na dan 22. IO. $2013(u \%)$

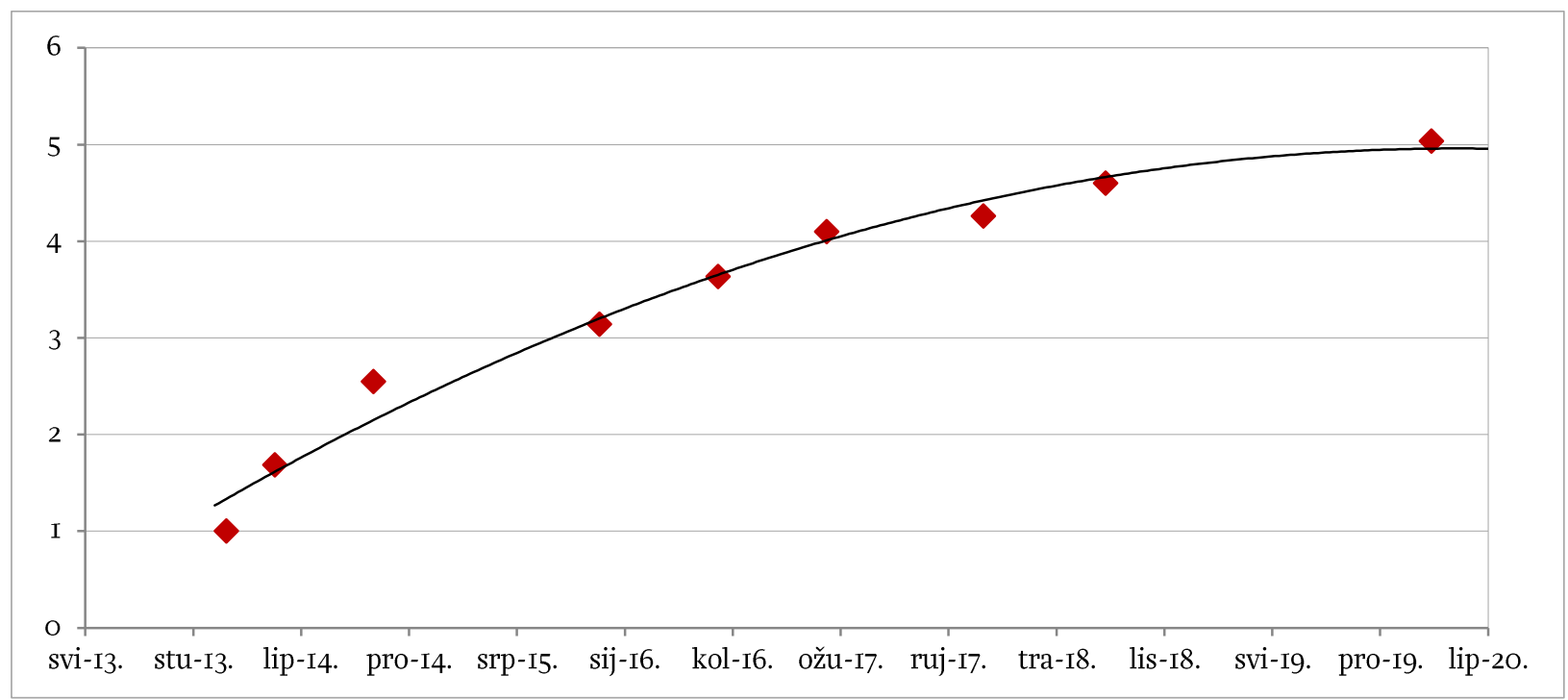

Izvor: Bloomberg (2013b)

\section{Grafikon 6.}

Prinosi do dospijeća obveznica Hrvatske, izdanih na domaćem tržištu denominiranih u eurima na dan 22. IO. 2013. $(u \%)$

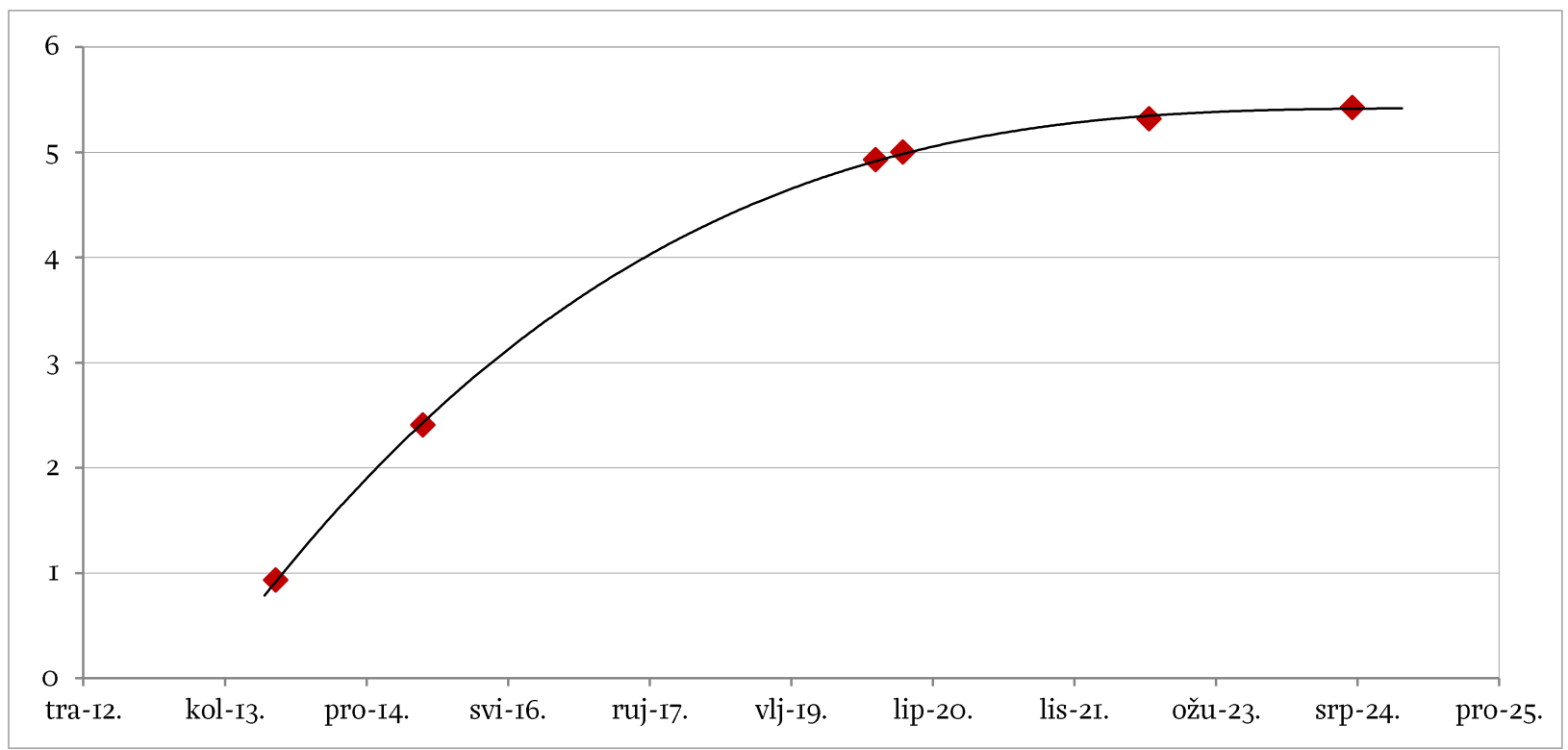

Izvor: Bloomberg (2013b) 


\section{Grafikon 7.}

Prinosi na dugoročne obveznice odabranih EU zemalja od 1993. do 2013. (u \%)

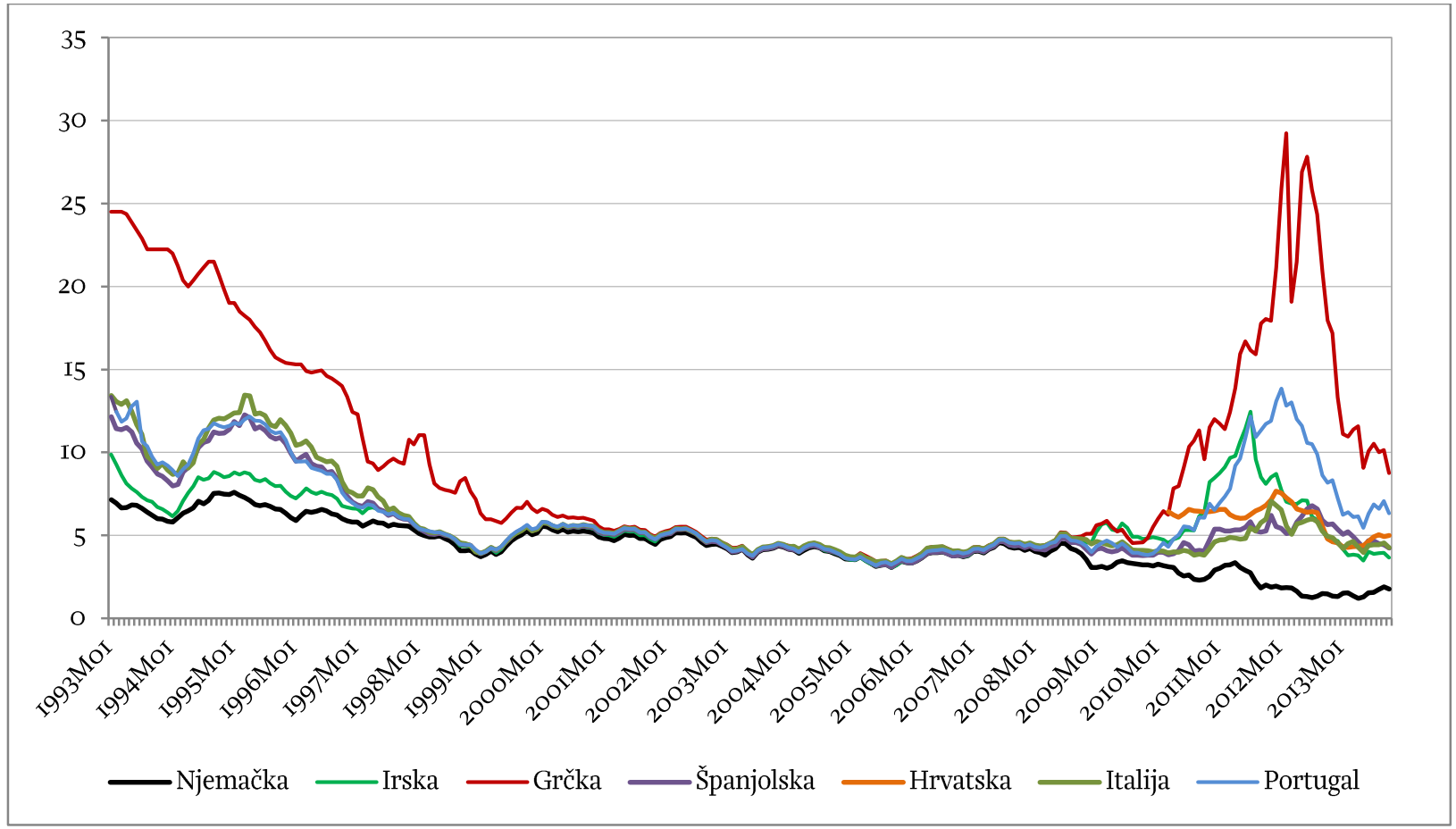

Napomena: Dugoročni prinosi na državne obveznice izračunati su kao mjesečni prosjeci. Odnose se na prinose državnih obveznica na sekundarnom tržištu s preostalim rokom dospijeća od oko Io godina. Obveznica ili obveznice (u portfelju) redovito se zamjenjuju kako bi se izbjegli potencijalni poremé́aji u ročnosti. Ova se definicija koristi i u kontekstu kriterija konvergencije Europske ekonomske i monetarne unije u pogledu ujednačenosti dugoročnih kamatnih stopa. Podaci za Hrvatsku dostupni su tek od ožujka $20 I 0$.

Izvor: Eurostat (2013)

\section{Grafikon 8.}

Kretanje prinosa na državne obveznice u EU, Grčkoj, Hrvatskoj i Njemačkoj (u \%)

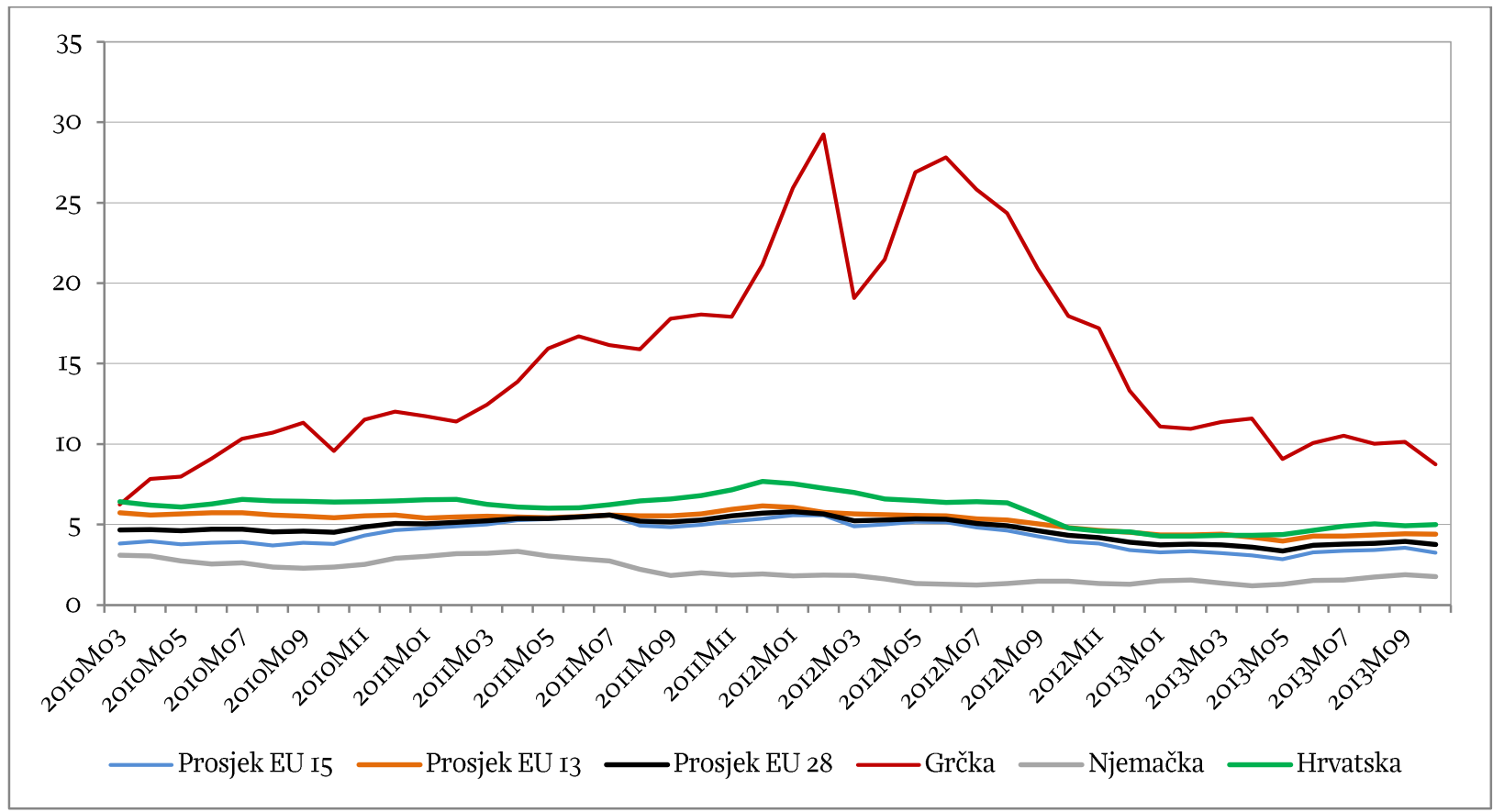

Napomena: vidi napomenu ispod grafikona 7.

Izvor: Eurostat (20I3)

IO NEWSLETTER83 | A. BAJO i M. PRIMORAC | Troškovi zaduživanja i prinosi na državne obveznice... | Institut za javne financije 


\section{LITERATURA}

Bajo, A., Primorac, M. i Andabaka Badurina, A., 20II. Osnove upravljanja javnim dugom. Zagreb: Institut za javne financije.

Bloomberg, 2013a. European Debt Crisis.

Bloomberg, 2013b. World market-bonds.

Ehrmann, M. [et al.], 2007. Convergence and Anchoring of Yield Curves int he Euro Area. European Central Bank, Working paper No. 817.

European Commision, 2013. Report from the Commision - Croatia. Report prepared in accordance with Article 126(3) of the Treaty, Brussels, 15.11.2013

Eurostat, 2013. Long term government bonds yield.

Ministarstvo financija, 2013a. Obrazloženje prijedloga Državnog proračuna za 20I4. Zagreb: Ministarstvo financija $\mathrm{RH}$.

Ministarstvo financija, 20I3b. Vremenske serije podataka - Konsolidirana opća država siječanj-rujan 2013. Zagreb: Ministarstvo financija RH. 